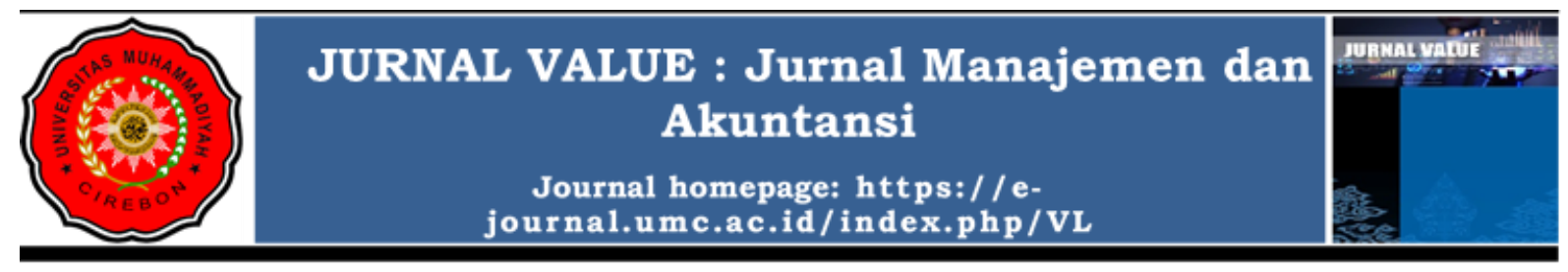

\title{
PENGARUH KEPEMIMPINAN TRANSFORMASIONAL TERHADAP ORGANIZATIONAL CITIZENSHIP BEHAVIOUR (OCB) MENUJU PENINGKATAN KINERJA KARYAWAN
}

\author{
Gugus Wijonarko ${ }^{1^{*}}$ \\ ${ }^{1}$ Ilmu Administrasi Bisnis Kepelabuhan, STIAMAK Barunawati \\ *Corresponden Author Email : wijonarko.gugus@gmail.com
}

Diterima : 15 Desember 2021 Direvisi : 20 Desember 2021 Dipublikasikan : 31 Desember 2021

\begin{abstract}
Abstrak
Sumber Daya Manusia adalah faktor kompleks dalam organisasi bisnis. perilaku manusia menjadi hal yang penting untuk diperhatikan, hal-hal terkait perasaan, motivasi dan kepuasan kerja merupakan sebagian dari pembentuk kinerja karyawan. peran pemimpin pun tidak kalah penting dalam membentuk perilaku karyawan, pemimpin tidak lagi berperan sebagai atasan saja tapi juga sebagai pendorong bagi karyawannya untuk mau berusaha lebih baik dalam meningkatkan produktivitas kerja mereka, pemimpina harus mampu membentuk perilaku karyawan agar secara sukarela mau berkorban bagi perusahaanya, peran perilaku konsumen ini dikenal dengan istilah Organizational Citizenship Behaviour (OCB). Pada penelitian ini akan mengambil tema yaitu peran kepemimpinan transformasional terhadap OCB dan berdampak kepada kinerja karyawan pada PT. $X Y Z$, dengan menggunakan metode penelitian yaitu menggunakan kuesioner dalam mendapatkan data yang dilakukan terhadap karyawan PT. XYZ dan metode pengambilan sampel menggunakan purporsive sampling. Hasil tanggapan responden didapatkan sejumlah 105 dan kemudian diolah menggunakan metode Structural Equation Modelling (SEM) dengan aplikasi SEM GSCA. Hasil penelitian yang diperoleh menyatakan bahwa faktor kepemimpinan transformasional berpengaruh kepada OCB dan selanjutnya mempengaruhi Kinerja Karyawan pada PT. XYZ.
\end{abstract}

Kata kunci: Kepemimpinan, OCB, Kinerja Karyawan, SEM

\section{PENDAHULUAN}

Organizational Citizenship Behaviour (OCBs) adalah perilaku karyawan yang tidak secara langsung menjadi bagian dari deskripsi pekerjaan karyawan yang melebihi persyaratan peran kerja mereka. Penelitian dari (Kinicki \& Williams, 2020) menunjukkan korelasi yang signifikan dan cukup positif antara perilaku kewargaan organisasi dan kepuasan kerja, produktivitas, efisiensi, dan kepuasan pelanggan. Faktor pembentuk OCB pada beberapa penelitian terdahulu adalah pengaruh dari gaya kepemimpinan dengan adanya pimpinan yang menerapkan gaya kepemimpinan transformasional dan keadilan organisasi, maka dapat menciptakan tingginya motivasi kerja dan kinerja karyawan pada sebuah organisasi (Avilla, 2017). Faktor kepemimpinan transformasional dianggap sebagai salah satu faktor yang baik dalam membentuk OCB dalam organisasi karena faktor kepemimpinan transformasional dapat mendorong tumbuhnya perasaan saling menolong dan adanya keinginan untuk mau membantu secara sukarela pekerjaan diantara para karyawan, hal ini dapat terjadi karena pemimpin selalu bertindak untuk mendorong bawahannya untuk berkontribusi pada pekerjaan melebihi dari kepentingan pribadinya (Darmawan \& Maisaroh, 2017).

Survey dari Salary Survey 2020 dikutip oleh Marketeers.com menyatakan bahwa pekerja profesional yang dipromosikan atau berpindah pekerjaan memiliki kesempatan untuk mendapatkan kenaikan gaji 15\% hingga 30\%, tergantung pada keahlian dan senioritas. Hasil survei ini juga menunjukkan bahwasanya terdapat beberapa alasan terjadinya turnover dilingkungan kerja antara lain 
adalah kejelasan jenjang karir, faktor pendapatan berupa kompensasi dan tunjangan yang lebih baik, serta budaya dan lingkungan kerja yang baik juga menjadi salah satu faktor pembentuk kepuasan kerja bagi profesional. Melihat dari fenomena ini maka sesuai dengan penelitian terdahulu dari (Prahesti et al., 2017) yang menyatakan bahwa faktor pembentuk OCB dan akan mempengaruhi kinerja karyawan adalah berasal dari kepuasan kerja. Karyawan yang merasa puas terhadap pekerjaan mereka akan mau mengeluarkan usaha lebih dalam meningkatkan kinerja mereka. Melihat dari latar belakang ini maka peneliti ingin mengambil tema penelitian terkait manajemen sumber manusia pada perusahaan PT. XYZ dengan mengetahui pengaruh antara kepemimpinan transformasional terhadap variabel OCB dan dampaknya terhadap kinerja karyawan.

\section{KAJIAN PUSTAKA \\ Manajemen Sumber Daya Manusia}

Pengertian dan fungsi dari manajemen sumber daya manusia adalah seluruh cakupan kegiatan yang berhubungan dengan proses perekrutan, manajemen pelatihan, penggajian dan kompensasi, hingga pada proses penghentian karyawan yang dikelola secara efektif dan efisien dalam rangka untuk mencapai tujuan perusahaan (Hussein et al., 2014). Fungsi manajemen sumber daya manusia sendiri meliputi kegiatan-kegiatan seperti (1) pengadaan sumber daya manusia, (2) pengembangan sumber daya manusia, (3) kompensasi, (4) pengintegrasian dan (5) pemeliharaan sumber daya manusia.

Penelitian terdahulu dari (Prihantoro, 2012) menyebutkan pula bahwa kinerja sumber daya manusia dipengaruhi kuat oleh faktor komitmen. Komitmen didalam sebuah organisasi merupakan kekuatan yang bersumber dari karyawan dalam mengidentifikasi keterlibatan dirinya pada organisasi. Beberapa hal ditandai sebagai berikut yaitu (1). Penerimaan terhadap nilai-nilai dan tujuan organisasi, (2) Kesiapan dan kesediaan untuk berusaha sungguh-sungguh atas nama organisasi dan (3). Keinginan untuk mempertahankan keanggotaan di dalam organisasi.

\section{Kepemimpinan Transformasional}

Gaya kepemimpinan transformasional (transformational leadership) adalah gaya kepemimpinan dimana seorang pimpinan berusaha untuk mengubah dan mendidik para karyawannya agar dapat memenuhi tujuan organisasi atau perusahaan daripada. Beberapa ciri-ciri dan indikator gaya kepemimpinan transformasional menurut Kreitner dan Kinicki tahun 2014 dikutip oleh (Burhanudin \& Kurniawan, 2020) antara lain:

1. Pemimpin membangun visi masa depan yang menarik

2. Pemimpin menunjukkan rasa optimis

3. Pemimpin menunjukkan rasa antusias

4. Pemimpin rela berkorban demi kebaikan bersama

5. Pemimpin dapat menjadi panutan, suri tauladan, dan contoh bagi para karyawan

6. Pemimpin menunjukkan standar etika yang tinggi dalam perilakunya

7. Pemimpin memberikan dukungan kepada para karyawan

8. Pemimpin memberikan semangat kepada para karyawan

9. Pemimpin memberikan pelatihan kepada para karyawan agar berkembang

10. Pemimpin memberdayakan karyawan

11. Pemimpin mendorong adanya inovasi; dan

12. Pemimpin mendorong upaya- upaya yang kreatif dalam memecahkan masalah- masalah yang dihadapi para karyawan.

Maka dari penjelasan diatas dapat dinyatakan bahwa kepemimpinan transformasional adalah pemimpin yang mempunyai kekuatan untuk mempengaruhi bawahan dengan cara-cara tertentu dalam menghadapi bawahnnya, agar bawahan merasa dipercaya, dihargai, loyal dan memiliki rasa hormat kepada pimpinannya. Hasil akhir yang diharapkan adalah bawahan akan termotivasi untuk melakukan lebih pada pekerjaan dari yang diharapkan baik dari sisi kualitas maupun kuantitas. beberapa indikator gaya kepemimpinan transformasional menurut Robbins dan Coulter tahun 2010 dalam (Hairudinor, Utomo dan Humaidi, 2020) yaitu sebagai berikut: (1) Kharisma, (2) Inspirasi, (3) Stimulasi Intelektual dan (4) Perhatian Individual. 


\section{Organizational Citizenship Behaviour (OCB)}

Pengertian OCB adalah kontribusi sukarela di tempat kerja yang mencakup perilaku membantu yang bersifat altruistik, kepatuhan kepada etika dan norma, persyaratan kerja, sopan santun kepada orang lain untuk memastikan hubungan kerja yang lancar, sportivitas untuk mempertahankan kinerja di bawah kesulitan, dan perilaku karyawan untuk berkontribusi secara konstruktif terhadap masalah yang muncul di tempat kerja (Vance, 2006). Indikator dari OCB berdasarkan dari aspek manfaat terhadap perusahaan menurut (Willyanto \& Hartawan, 2013) adalah:

1. Altruism, merupakan perilaku karyawan yang berupa kesadaran untuk membantu rekan kerjanya yang mengalami kesulitan dalam situasi yang sedang dihadapi baik terhadap pekerjaan dalam organisasi maupun pada masalah pribadi

2. Civic virtue, merupakan perilaku yang mengindikasikan tanggung jawab pada lingkungan organisasi dimana karyawan memiliki kecenderungan untuk mengikuti perubahan dalam organisasi, mengambil inisiatif untuk perbaikan prosedur dan proses bisnis organisasi, dan melindungi sumber daya organisasi.

3. Conscientiousness, adalah perilaku yang menyebabkan karyawan termotivasi untuk bekerja melebihi dari apa yang diharapkan oleh perusahaan. Perilaku sukarela ini bukan merupakan kewajiban atau tugas dari karyawan yang bersangkutan melainkan lebih kepada kesadaran pribadi karyawan itu sendiri

4. Courtesy, merupakan perilaku dalam menjaga hubungan baik dengan sesama rekan kerja agar terhindar dari masalah ataupun konflik antar karyawan, sehingga orang yang memiliki perilaku courtesy ini adalah orang yang menghargai dan memperhatikan orang lain.

5. Sportsmanship, merupakan perilaku yang digambarkan dengan memberikan toleransi terhadap keadaan yang kurang ideal dalam organisasi tanpa mengajukan keberatan

\section{Kinerja Karyawan}

Kinerja Karyawan merupakan hasil kerja yang dicapai oleh seseorang baik secara individu maupun dalam kelompok pada suatu organisasi sesuai dengan tugas, wewenang dan tanggung jawabnya masing-masing. Kinjerja karyawan bertujuan untuk mencapai tujuan organisasi yang bersangkutan secara legal atau tidak melanggar hukum dan sesuai dengan moral dan etika (Monalis, 2013). Kepuasan kerja dapat dinyatakan mempengaruhi kinerja karyawan apabila kepuasan yang diperoleh dan dirasakan oleh karyawan dari pekerjaanya apabila terdapat kesesuaian antara apa yang diharapkan dengan apa yang diterima sehingga mampu mendorong karyawan untuk mencapai kinerja yang optimal.

Penelitian terdahulu dari (Prahesti et al., 2017) menunjukkan bahwa penurunan kinerja karyawan juga dapat dipengaruhi oleh faktor OCB karyawan. OCB sendiri sejatinya adalah perilaku pilihan yang tidak menjadi bagian dari kewajiban kerja formal seorang karyawan. Akan tetapi karyawan yang memiliki OCB tinggi terhadap tempat ia berkerja maupun pada karyawan lainnya akan memunjukkan kinerja yang meningkat serta sikap adaptasi yang lebih baik seperti mudah bergaul, ramah, dan lebih mudah untuk dapat bersedia menerima pekerjaan yang ia dapatkan tanpa disertai rasa mengeluh maupun membantah.

Mangkunegara 2009 dalam (Septyan et al., 2017) berpendapat bahwa kinerja adalah hasil kerja secara kualitas dan kuantitas yang dicapai oleh seorang karyawan dalam melaksanakan tugasnya sesuai dengan tanggung jawab yang diberikan kepadanya, sehingga dapat dinyatakan bahwa indikator yang dijadukan dasar pengukuran kinerja yaitu sebagai berikut:

Indikator Kuantitas dengan ukuran berikut:

1. Jumlah hasil kerja sesuai dengan standar yang ditetapkan

2. Jumlah hasil kerja lebih banyak dibanding dengan waktu yang lalu

3. Jumlah hasil kerja lebih banyak dibandingkan dengan rekan kerja

Indikator Kualitas, dengan ukuran sebagai berikut:

1. Pencapaian mutu hasil kerja sesuai dengan standar yang ditetapkan

2. Pencapaian mutu hasil kerja lebih baik dibandingkan dengan waktu yang lalu

3. Pencapaian mutu hasil kerja labih baik dibandingkan dengan rekan kerja

Ketepatan waktu kerja dengan ukuran sebagai berikut:

1. Waktu penyelesaian pekerjaan sesuai dengan standar perusahaan 
2. Waktu penyelesaian pekerjaan lebih cepat dibandingkan dengan waktu yang lalu

3. Waktu penyelesaian pekerjaan lebih cepat dibandingkan dengan rekan kerja

\section{PENGEMBANGAN HIPOTESIS}

\section{Pengaruh Kepemimpinan Transformasional terhadap Organizational Citizenship Behaviour} $(\mathrm{OCB})$

Peneltian terdahulu dari (Prahesti et al., 2017) menunjukkan bahwa terdapat hubungan antara kepemimpinan transformasional terhadap OCB. Pemimpin merupakan figur utama dalam memberikan motivasi dan dukungan kepada karyawannya untuk mengembangkan diri masing-masing karyawannya. Penelitian lainnya juga mendukung teori yang sama dengan menyatakan bahwa pemimpin yang dapat dipercaya oleh bawahannya akan mempengaruhi faktor OCB (Juniartha et al., 2017). Dengan mengacu pada beberapa penelitian tersebut maka dirumuskan hipotesis sebagai berikut:

H1: Kepemimpinan Transformasional berpengaruh terhadap Organizational Citizenship Behaviour $(O C B)$.

\section{Pengaruh Organizational Citizenship Behaviour $(O C B)$ terhadap Kinerja Karyawan}

Karyawan yang telah membentuk perilaku berdasarkan OCB maka akan memiliki dampak yang positif terhadap kinerjanya. Hal ini terbukti bahwa organisasi yang baik akan membutuhkan sumber daya manusia yang handal dalam mencapai produktivitas mereka (Prahesti et al., 2017). Perilaku OCB akan terbentuk saat karyawan merasakan kepuasan dalam bekerja. Perasaan puas inilah yang akan membuat karyawan ingin bekerja lebih baik dan berkontribusi penuh terhadap proses pencapaian tujuan perusahaan (Lukito, 2020). Berdasarkan penelitian ini maka dirumuskan hipotesis sebagai berikut ini:

H2: Organizational Citizenship Behaviour $(O C B)$ berpengaruh terhadap Kinerja Karyawan.

\section{METODE PENELITIAN}

Metode pengolahan data yang akan digunakan pada penelitian ini adalah mengunakan metode Structural Equation Modelling (SEM). SEM merupakan teknik olah data statistik yang digunakan untuk membangun dan menguji pemodelan statistik dalam bentuk model hubungan sebab akibat (Sarwono, 2010). SEM pada perkembangannya mempunyai fungsi yang hampir mirip dengan analisis regresi berganda, tetapi SEM dianggap memiliki teknik analisis yang lebih kuat karena mempertimbangkan pemodelan interaksi, nonlinearitas, variabel-variabel bebas yang berkorelasi (correlated independents), kesalahan pada pengukuran, gangguan kesalahan-kesalahan yang berkorelasi (correlated error terms), beberapa variabel bebas laten (multiple latent independents) dimana setiap variabel diukur dengan mempertimbangkan pula jumlah indikator yang digunakan. Model penelitian yang akan digunakan adalah seperti pada gambar 1. berikut ini:

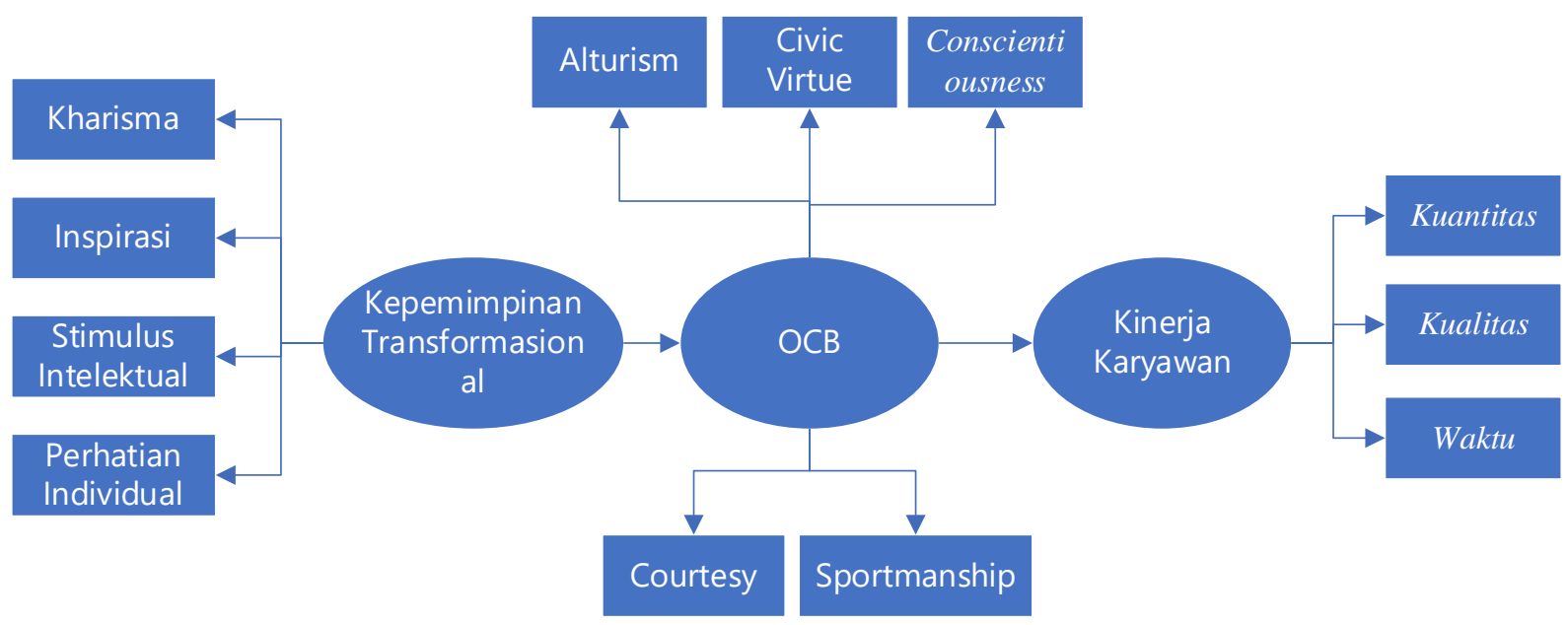

Gambar 1. Kerangka Penelitian

Sumber: Olahan Peneliti 


\section{Skala Likert}

Skala Likert merupakan skala yang sering digunakan dalam melakukan pengukuran persepsi, sikap atau pendapat seseorang atau kelompok terkait studi kasus atau fenomena yang diangkat. Pada skala likert terdapat dua bentuk pertanyaan atau pernyataan yang digunakan dalam melakukan pengukuran, yaitu bentuk positif untuk mengukur skala positif dan bentuk negatif untuk mengukur skala negatif (Pranatawijaya et al., 2019). Pada penelitian ini digunakan skala likert bentuk positif dengan skala pengukuran meliputi (5) Sangat Setuju, (4) Setuju, (3) Netral, (2) tidak setuju, dan (1) sangat tidak setuju.

\section{Metode Pengambilan Sampel}

Metode pengambilan sampel pada penelitian ini menggunakan purposive sampling, metode ini mengambil sampel acak dengan target sampel merupakan karyawan PT XYZ baik dari jajaran pimpinan maupun dari pihak karyawan. Purposive sampling digunakan dengan pertimbangan bagi peneliti dimana sampel diambil berdasarkan keputusan peneliti untuk mencari responden yang dianggap tepat dan bersedia memberikan informasi berdasarkan pengetahuan dan pengalamannya (Chandra \& Wirapraja, 2020). Populasi dari PT. XYZ Surabaya berkisar sekitar 150 karyawan, pendugaan parameter terhadap populasi dan sampel akan menggunakan metode kemungkinan maksimum (maximum likelihood estimation) dengan besar sampel ditentukan melalui beberapa langkah berikut:

1. 5 dikali jumlah indikator penelitian ini yaitu sebanyak 12 indikator sehingga mendapatkan sampel minimum adalah 60 .

2. 10 dikali jumlah indikator penelitian (12 indikator) sehingga didapatkan sampel maksimum adalah 120 .

3. Sehingga dapat disimpulkan bahwa sampel penelitian yang akan digunakan dalam penelitian ini berkisar antara 60-120 sampel.

Profil dari responden pada penelitian ini adalah:

1. Karyawan dari berbagai divisi dan departemen di PT. XYZ Surabaya

2. Memiliki jenis kelamin Pria dan Wanita

3. Rentang umur responden antara 21 hingga 52 Tahun

\section{HASIL DAN PEMBAHASAN}

PT. XYZ merupakan perusahaan pada bidang kontraktor pekerjaan umum (General Contractor) yang berpusat di Jakarta dan memiliki kantor cabang di Surabaya dan Bali. PT. XYZ menyelesaikan proyek dengan standard of quality yang dipercaya hanya dapat dicapai dengan menerapkan integrasi pada setiap tahap dari mempelajari desain, perencanaan, konstruksi dan pemeliharaan. Dalam rangka menghadapi tuntutan dari pemerintah terhadap terget jangka panjang dari program infrastruktur serta persaingan yang ketat antar perusahaan kontruksi, maka perlu dilakukan perbaikan dan peningkatan kinerja dan produktivitas kerja dari karyawan. Kinerja karyawan dan produktivitas kerja menurut penelitian terdahulu dinyatakan bahwa untuk mencapai kedua hal ini maka para pekerja harus memiliki rasa puas terlebih dahulu dalam pekerjaan mereka (Setiawan, 2021) (Kurniawan, 2015).

\section{Profil Responden Penelitian}

Profil responden yang menjadi sampel pada penelitian adalah individu yang telah mengisi kuesioner dan merupakan karyawan dari PT. XYZ sejumlah 105 responden dengan rentang umur antara 21-52 tahun dengan jenis kelamin laki-laki sebanyak 57,6\% dan perempuan sebesar $42,4 \%$. Responden yang didapatkan berasal dari berbagai departemen atau divisi dalam PT. XYZ dengan mengabaikan posisi dan jabatan yang emban oleh para responden saat ini.

\section{Analisa SEM}

Hasil pengukuran dan pengolahan data menggunakan metode SEM yang dilakukan dengan menggunakan aplikasi GSCa Pro 1.1.5 diperoleh hasil sebagai berikut:

Tabel 1. Pengukuran Model Fit

\begin{tabular}{ccccccccc}
\hline FIT & AFIT & FITs & FITm & GFI & SRMR & OPE & OPEs & OPEm \\
\hline 0.905 & 0.903 & 0.627 & 0.975 & 1.0 & 0.017 & 0.095 & 0.375 & 0.025 \\
\hline
\end{tabular}

Sumber: Olahan Peneliti 
Berdasarkan tabel 1 diketahui beberapa keterangan menurut (Hwang et al., 2021) antara lain:

1. FIT: harus diatas 0,50 (FIT $\geq 0,50$ ) hasil estimasi adalah 0,905 maka dapat disimpulkan bahwa tingkat kecocokan model baik (goodfit)

2. AFIT: harus diatas 0,50 (AFIT $\geq 0,50$ ) hasil estimasi adalah 0,903 maka dapat disimpulkan bahwa tingkat kecocokan model baik (goodfit)

3. FITs: menunjukkan varians total dari semua komponen yang dijelaskan oleh spesifikasi model struktural tertentu. Nilai FITS berkisar dari 0 hingga 1. Semakin besar nilai ini, semakin banyak varians dalam komponen yang diperhitungkan oleh model struktural yang ditentukan. Dari hasil pengukuran didapatkan hasil sebesar 0,627 sehingga dapat disimpulkan bahwa benar model memiliki varian dan komponen dalam membentuk model struktural tersebut.

4. FITm: menunjukkan varians total dari semua indikator yang dijelaskan oleh spesifikasi model pengukuran tertentu. Nilai FITM berkisar dari 0 hingga 1. Semakin besar nilai ini, semakin banyak varians dalam indikator yang diperhitungkan oleh model pengukuran yang ditentukan. Hal ini dapat dibuktikan dengan nilai FITM pada penelitian ini yang mendekati 1 yaitu sebesar 0,975

5. GFI: harus diatas 0,95 , Skala antara 0 dan 1 , dengan nilai yang lebih tinggi menunjukkan kesesuaian model yang lebih baik. Pada pengolahan data ini hasil yang didapatkan adalah 1.0 yang berarti model penelitian ini memiliki kesesuaian yang sangat baik

6. SRMR: Nilai yang diperkenankan untuk SRMR sebenarnya berkisar dari 0 hingga 1 , dan nilai terbaik adalah apabila model fit memiliki nilai kurang dari 0,05 namun apabila dari hasil pengolahan didapatkan nilai setinggi 0,08 maka model tersebut masih dapat ditoleransi untuk dapat diterima. Hasil pengolahan data pada penelitian ini mendapatkan nilai 0,017 yang berarti nilai tersebut kurang dari 0,05 hal ini membuktikan pula bahwa model ini dianggap sebagai model yang fit.

Tabel 2. Nilai Weights

\begin{tabular}{ccccc}
\hline & Estimate & SE & \multicolumn{1}{c}{ 95\% CI } \\
\hline \multicolumn{5}{c}{ Kepemimpinan Transformasional } \\
\hline kt1 & 0.294 & 0.038 & 0.217 & 0.362 \\
\hline kt2 & 0.2 & 0.026 & 0.182 & 0.269 \\
\hline kt3 & 0.238 & 0.075 & 0.082 & 0.395 \\
\hline kt4 & 0.274 & 0.078 & 0.08 & 0.402 \\
\hline \multicolumn{5}{c}{ Organizational Citizenship Behaviour } \\
\hline ocb1 & 0.211 & 0.03 & 0.149 & 0.259 \\
\hline ocb2 & 0.19 & 0.01 & 0.168 & 0.209 \\
\hline ocb3 & 0.19 & 0.01 & 0.168 & 0.209 \\
\hline ocb4 & 0.19 & 0.01 & 0.168 & 0.209 \\
\hline ocb5 & 0.232 & 0.021 & 0.188 & 0.27 \\
\hline \multicolumn{5}{c}{ Kinerja Karyawan } \\
\hline kk1 & 0.284 & 0.012 & 0.259 & 0.301 \\
\hline kk2 & 0.491 & 0.009 & 0.474 & 0.508 \\
\hline kk3 & 0.249 & 0.013 & 0.231 & 0.281 \\
\hline \multicolumn{5}{c}{}
\end{tabular}

Sumber: Olahan Peneliti 
Nilai weight dapat dihubungan dengan reliabilitas indikator dari variabel konstruk, dan nilai yang diperkenankan adalah minimal 0,2 dari data pada tabel 2 diketahui bahwa pada seluruh indikator dari seluruh variabel yang digunakan pada penelitian ini berada pada nilai 0,2 .

Tabel 3. Nilai Loadings

\begin{tabular}{ccccc}
\hline & Estimate & SE & 95\% CI \\
\hline \multicolumn{5}{c}{ Kepemimpinan Transformasional } \\
\hline kt1 & 0.994 & 0.002 & 0.988 & 0.997 \\
\hline kt2 & 0.993 & 0.003 & 0.987 & 0.997 \\
\hline kt3 & 0.992 & 0.003 & 0.984 & 0.997 \\
\hline kt4 & 0.994 & 0.002 & 0.989 & 0.997 \\
\hline \multicolumn{5}{c}{ Organizational } \\
\hline ocb1 & 0.988 & 0.005 & 0.977 & 0.994 \\
\hline ocb2 & 0.995 & 0.002 & 0.991 & 0.997 \\
\hline ocb3 & 0.995 & 0.002 & 0.991 & 0.997 \\
\hline ocb4 & 0.995 & 0.002 & 0.991 & 0.997 \\
\hline ocb5 & 0.974 & 0.008 & 0.95 & 0.984 \\
\hline \multicolumn{5}{c}{ Kinerja Karyawan } \\
\hline kk1 & 0.969 & 0.013 & 0.935 & 0.982 \\
\hline kk2 & 0.977 & 0.007 & 0.957 & 0.984 \\
\hline kk3 & 0.981 & 0.007 & 0.964 & 0.988 \\
\hline
\end{tabular}

Sumber: Olahan Peneliti

Individual Item Reliability: dapat dilihat dari nilai standardized loading factor pada SEM GSCA tabel 3 menampilkan hasil nilai estimate pada loading factor pada keseluruhan item berada di atas 0,9. Nilai loading factor secara definisi menggambarkan besarnya korelasi antara setiap item pengukuran (indikator) dengan konstruknya, pada penelitian dari (Putri \& Jumhur, 2019) disebutkan bahwa minimal nilai loading factor adalah sebesar 0,5. Sedangkan penelitian dari (Kristi, 2020) menyebutkan bahwa Nilai loading factor yang dianggap ideal adalah bila nilai tersebut $>0.7$. dari hasil perhitungan olah data pada SEM GSCA dapat dinyatakan bahwa seluruh indikator dalam penelitian ini dinyatakan valid.

Tabel 4. Koefisien Jalur

\begin{tabular}{ccccc}
\hline & Estimate & SE & \multicolumn{2}{c}{ 95\% CI } \\
\hline $\mathrm{KT} \rightarrow \mathrm{OCB}$ & 0.958 & 0.012 & 0.934 & 0.975 \\
\hline $\mathrm{OCB} \rightarrow \mathrm{KK}$ & 0.981 & 0.006 & 0.964 & 0.988 \\
\hline
\end{tabular}

Sumber: Olahan Peneliti

Pada tabel 4 dapat kita simpulkan bahwa hubungan antara variabel kepemimpinan transformasional kepada variabel Organizational Citizenship Behaviour (OCB) memiliki nilai estimate sebesar 0,958, sedangkan variabel OCB kepada variabel Kinerja Karyawan memiliki nilai sebesar 0,981 dengan tingkat error sebesar 5\% didapatkan pula nilai SE sebesar 0,012 dan 0,006. Maka dapat ditarik kesimpulan bahwa kepemimpinan transformasional berpengaruh signifikan terhadap variabel Organizational Citizenship Behaviour $(O C B)$ dan mempengaruhi pula secara positif signifikan terhadap kinerja karyawan pada PT. XYZ.

Pemimpin yang ideal diyakini akan mampu menumbuhkan motivasi dan semangat kerja dari para karyawan untuk mengeluarkan potensi terbaik mereka dalam menyelesaikan dan mengerjakan 
tugas dan tanggung jawab mereka. Karyawan yang memiliki etos kerja yang baik maka secara langsung juga akan meningkatkan performa kinerja dari karyawan itu sendiri sehingga akan berdampak kepada produktivitas perusahaan secara keseluruhan.

\section{PEMBAHASAN}

\section{Hipotesis 1 Kepemimpinan Transformasional mempengaruhi Organizational Citizenship Behaviour (OCB).}

Kepemimpinan pada PT. XYZ berdasarkan tanggapan responden telah dianggap baik sejauh ini, pemimpin bagi sebagai besar karyawan mampu memotivasi mereka dalam bekerja sehingga dapat meningkatkan beberapa hal seperti, keinginan berkorban bagi perusahaan, rasa tanggung jawab yang lebih besar serta peningkatan terhadap efektivitas kerja mereka, hal ini dibuktikan dari hasil pengolahan data didapatkan bahwa nilai estimate sebesar 0,958 dan nilai SE sebesar 0,012 menunjukkan bahwa memang terbukti bahwa terdapat hubungan yang positif signifikan antara kepemimpinan transformasional dan OCB. Hasil ini berarti hasil penelitian ini telah sesuai dengan penelitian terdahulu pada rumusan hipotesis yang menyatakan bahwa kepemimpinan transformasional berpengaruh terhadap OCB, maka dapat disimpulkan bahwa hipotesis 1 diterima. Hasil ini juga sesuai dengan penelitian dari (Prahesti et al., 2017) dan (Juniartha et al., 2017) yang menyebutkan bahwa kepemimpinan transformasional memiliki pengaruh besar terhadap Organizational Citizenship Behaviour (OCB).

\section{Hipotesis 2 Organizational Citizenship Behaviour $(O C B)$ mempengaruhi Kinerja Karyawan.}

Berdasarkan hasil penelitian didapatkan pengaruh positif antara perlaku OCB terhadap kinerja karyawan dengan nilai estimate diatas $(>0,9)$ pada tingkat error $5 \%$ maka dapat dinyatakan bahwa sebagian besar dari responden setuju bahwa semakin tingginya perasaan puas yang mereka rasakan melalui indikator OCB ini maka kinerja mereka pun menjadi semakin baik. OCB dalam peranannya perlu mendapat dukungan dari pemimpin, maka dari penelitian ini dapat terlihat bahwa peranan pemimpin lebih dahulu membentuk OCB, dan persepsi positif ini akan berdampak pula terhadap meningkatnya kinerja karyawan pada PT. XYZ Surabaya. Berdasarkan hal ini dapat disimpulkan bahwa hipotesis 2 dapat diterima. Hasil dari penelitian ini diperkuat oleh penelitian dari (Abrar \& Isyanto, 2019) yang menyatakan bahwa karyawan dengan perilaku OCB yang baik akan menghasilkan dampak bagi organisasinya melalui kinerja pekerjaan yang lebih baik. Penelitian dari (Bustomi et al., 2020) menyatakan pula bahwa OCB dibutuhkan bagi PT. XZY sebagai bentuk perwujudan dari komitmen karyawan dalam mementingkan organisasi dibandingkan kebutuhan pribadinya.

\section{KESIMPULAN}

Berdasarkan hasil penelitian yang telah dilakukan maka dapat disimpulkan bahwa kepemimpinan transformasional memegang peranan penting dalam membentuk OCB khususnya pada perusahaan XYZ. OCB sendiri secara definisi merupakan perilaku karyawan yang secara sadar dan sukarela bersedia untuk membantu rekan kerja dan mengembangkan perusahaan tempat mereka bekerja sehingga dapat meningkatkan kinerja pekerjaan pada PT. XYZ. Hasil dari penelitian menunjukkan bahwa terbukti pada perusahaan XYZ faktor kepemimpinan memiliki pengaruh kuat dalam membentuk perilaku yang sesuai dengan konsep OCB, hal ini dibuktikan dengan nilai estimate sebesar 0,958 atau diatas 0,9 yang menyatakan bahwa kepemimpinan memiliki pengaruh yang signifikan terhadap OCB. Sedangkan pengaruh OCB sendiri bagi sebagian besar karyawan PT. XYZ juga memiliki pengaruh yang positif signifikan dalam meningkatkan kinerja karyawan yang juga mendapatkan hasil diatas 0,9 yaitu sebesar 0,981.

\section{SARAN}

\section{Saran Praktis}

Saran praktis pada PT. XYZ adalah hasil dari penelitian diketahui bahwa kepemimpinan memegang peranan penting dalam membentuk perilaku karyawan, dan hal ini di tegaskan kembali bahwa perilaku karyawan berdampak signifikan pula terhadap kinerja karyawan. maka tugas utama dari para pemegang kebijakan adalah perlunya melakukan pelatihan dan sosialisasi kepada para pemimpin baik pada level manajemen atas maupun pada level 
manajemen menengah agar dapat menjadi "role model" yang baik bagi karyawannya. Pelatihan yang dimaksud adalah dari sisi komunikasi dan kemampuan kompetensi yang dimiliki oleh pemimpin agar lebih mudah dan jelas dapat memberikan arahan kepada bawahannya. Hasil ini juga dapat menjadi perbaikan dari sisi manajerial pada PT. XYZ sebagai dasar pengambilan kebijakan khususnya pada bidang sumber daya manusia dalam menentukan mencari figur pemimpin yang transformasional dan melakukan pembuatan perencanaan untuk meningkatkan kepuasan karyawan yang dapat mendukung kinerja organisasi.

2. Saran Teoritis

Saran teoritis yang dapat dilakukan dalam pengembangan penelitian ini adalah bahwa peneliti selanjutnya dapat menambahkan variabel-variabel penelitian yang terkait dengan perubahan perilaku karyawan contohnya seperti variabel motivasi, kepuasan kerja dan produktivitas kerja yang berhubungan dengan transformasi digital khususnya pada era industri 4.0 dimana transformasi digital berpengaruh kuat pada organisasi saat ini dalam membentuk pola perilaku dan perubahan pada proses kerja dari manajemen rutinitas operasional harian.

\section{REFERENSI}

Abrar, U., \& Isyanto, I. (2019). Pengaruh Organizational Citizenship Behaviour (OCB) Terhadap Kinerja Karyawan (Studi Pada Pt. Urchindize Cabang Madura). Jurnal Perilaku Dan Strategi Bisnis, 7(2), 115. https://doi.org/10.26486/jpsb.v7i2.868

Avilla, G. (2017). GAYA KEPEMIMPINAN TRANSFORMASIONAL, KEADILAN ORGANISASI, DAN REAKSI KARYAWAN TERHADAP KINERJA KARYAWAN. Jurnal Manajemen Dan Pemasaran Jasa, 10(1), 128-140.

Burhanudin, \& Kurniawan, A. (2020). Gaya Kepemimpinan Transaksional Dan Transformasional Terhadap Kinerja Karyawan Bank Bri Purworejo. Media Riset Bisnis \& Manajemen, 1(X1), 7 18. https://trijurnal.lemlit.trisakti.ac.id/mrbm/article/view/6324

Bustomi, A., Sanusi, I., \& Herman, H. (2020). Pengaruh Organizational Citizenship Behavior (OCB) Terhadap Kinerja Pegawai Kementerian Agama Kota Bandung. Tadbir: Jurnal Manajemen Dakwah, 5(1), 1-16. https://doi.org/10.15575/tadbir.v5i1.2002

Chandra, W., \& Wirapraja, A. (2020). The Effect of Application Usability, Service Quality , and ESatisfaction on Purchase Intention of GoFood Customers. Indonesian Journal of Information Systems, 3(1), 38-49.

Darmawan, A., \& Maisaroh, M. (2017). Pengaruh kepemimpinan transformasional dan kepuasan kerja terhadap organizational citizenship behavior pada Islamic Boarding School tingkat SMA di Yogyakarta. Jurnal Aplikasi Bisnis, 17(2), 93-113. https://doi.org/10.20885/jabis.vol17.iss2.art6

Hairudinor, Utomo, S., \& Humaidi. (2020). Pengaruh Gaya Kepemimpinan Transformasional, Motivasi Kerja, Dan Budaya Organisasi Terhadap Kinerja Karyawan. Jurnal Administrasi Bisnis Vol., 10(1), 48-54.

Hussein, F., Kertahadi, \& Riyadi. (2014). IMPLEMENTASI SISTEM INFORMASI SUMBER DAYA MANUSIA (Studi Kasus pada Perusahaan Jasa PT . Wiranas Laundry and Dry Cleaning Service ). Jurnal Administrasi Bisnis, 10(1), 1-11.

Hwang, H., Cho, G., \& Choo, H. (2021). GSCA Pro 1.1 User's Manual. https://doi.org/10.13140/RG.2.2.28162.61127

Juniartha, I., Wardana, I., \& Putra, M. (2017). Pengaruh Kepemimpinan Transformasional Terhadap Organizational Citizenship Behavior (Ocb) Melalui Mediasi Kepercayaan Kepada Atasan Dan Kepuasan Kerja (Studi Pada Pegawai Tetap Balai Diklat Industri Kementerian Perindustrian Republik Indonesia). Buletin Studi Ekonomi, 21(2), 181-196. https://doi.org/10.24843/bse.2016.v21.i02.p07

Kinicki, A., \& Williams, B. K. (2020). Management: A Practical Introduction (9e ed.). McGraw-Hill.

Kristi, B. N. (2020). Faktor-Faktor Yang Mempengaruhi Niat Perilaku Pengguna Dan Niat Untuk Merekomendasikan Aplikasi Ovo. Universitas Sanata Darma.

Kurniawan, D. (2015). PENGARUH GAYA KEPEMIMPINAN TRANFORMASIONAL DAN KOMPENSASI TERHADAP PRODUKTIVITAS KERJA KARYAWAN PT. SPORT GLOVE INDONESIA. Universitas Negeri Yogyakarta. 
Lukito, R. (2020). Pengaruh Organizational Citizenship Behavior Terhadap Kinerja Karyawan Melalui Kepuasan Kerja Pada Produksi PVC di UD. Untung Jaya Sidoarjo. Agora, 8(2), 1-9. http://publication.petra.ac.id/index.php/manajemen-bisnis/article/view/10599

Monalis, E. (2013). Pengembangan Sumber Daya Manusia dan Kinerja Karyawan. Jurnal EMBA, 1(3), 1080-1088.

Prahesti, D. S., Riana, I. G., \& Wibawa, I. M. A. (2017). Pengaruh Kepemimpinan Transformasional Terhadap Kinerja Karyawan Dengan Ocb Sebagai Variabel Mediasi. E-Jurnal Ekonomi Dan Bisnis Universitas Udayana, 7, 2761-2787. https://doi.org/10.24843/eeb.2017.v06.i07.p06

Pranatawijaya, V. H., Widiatry, W., Priskila, R., \& Putra, P. B. A. A. (2019). Penerapan Skala Likert dan Skala Dikotomi Pada Kuesioner Online. Jurnal Sains Dan Informatika, 5(2), 128-137. https://doi.org/10.34128/jsi.v5i2.185

Prihantoro, A. (2012). PENINGKATAN KINERJA SUMBER DAYA MANUSIA MELALUI MOTIVASI, DISIPLIN, LINGKUNGAN KERJA, DAN KOMITMEN. Value Added, 8(2), 78 98.

Putri, R. A., \& Jumhur, H. M. (2019). Peminat Aplikasi Blibli.com dengan Menggunakan Model Unified Theory Of Acceptance And Use Of Technology (UTAUT). Jurnal Riset Bisnis Dan Manajemen, 12(2), 16-23.

Sarwono, Y. (2010). Pengertian Dasar Structural Equation Modeling (SEM). Jurnal Ilmiah Manajemen Bisnis Ukrida, 10(3), 98528.

Septyan, F. B., Musadieq, M. Al, \& Mukzam, M. D. (2017). MOTIVASI DAN KINERJA ( Studi Pada Karyawan CV . Jade Indopratama Malang ). Jurnal Administrasi Bisnis (JAB), 53(1), 8188. http://administrasibisnis.studentjournal.ub.ac.id/index.php/jab/article/viewFile/2185/2583

Setiawan, E. Y. (2021). PENGARUH GAYA KEPEMIMPINAN TRANSFORMASIONAL DAN TRANSAKSIONAL TERHADAP KINERJA KARYAWAN PT. ISS INDONESIA DI RUMAH SAKIT NATIONAL SURABAYA. Ilmu Manajemen MAGISTRA, 1(1), 255-277. https://doi.org/10.1201/9780429290657-11

Vance, R. J. (2006). Engagement and Commitment. In SHRM Foundation's effective Practice Guidelines. https://www.shrm.org/hr-today/trends-and-forecasting/special-reports-and-expertviews/Documents/Employee-Engagement-Commitment.pdf

Willyanto, M. Y., \& Hartawan, P. C. (2013). Organization Citizenship Behavior Yang Berpengaruh Pada Kualitas Layanan Dan Kepuasan Konsumen Di Hotel JW Marriott Surabaya. Jurnal Hospitality Dan Manajemen Jasa, 1(3), 305-320. 